\title{
9 \\ The Fiji military and the 2014 elections
}

\author{
Jone Baledrokadroka
}

\section{Introduction}

The role of the military in Fiji's politics over the last 27 years has been decisive. Four military coups followed by democratic elections have indelibly shaped Fiji's political landscape. Held under the 2013 Constitution imposed on Fiji by the Bainimarama regime, Fiji's September 2014 elections were hailed by the coordinator of the Multinational Observer Group as 'broadly reflecting the will of the people' (Goledzinowski 2014). The readiness of the international community to sanction the polls after eight years of authoritarian rule underscores the pragmatism of realpolitik as also shown by the people of Fiji, ${ }^{1}$ whose acquiescence to military intervention is now a hallmark of politics in the country. At the October 2014 swearing in of the new parliament after eight years of dictatorship, the 10 democratically elected former military officers, including several other members of FijiFirst (FF), all wore regimental neckties. In a sense, this display

\footnotetext{
1 In projecting forward the 2007 census percentages to September 2014, indigenous Fijians would make up 62 per cent and Indo-Fijians 34 per cent of the 591,101 registered voters.
} 
of solidarity symbolised the pervasiveness of the Fiji military's political power. ${ }^{2}$ Against this broad background, this chapter analyses the role of the military and its impact on the election outcome.

The most likely scenario is that former coup leader, and now elected Prime Minister, Frank Bainimarama, will be around for another four years until the 2018 elections - a total of 12 years in power. But the military is likewise destined to remain close to the centre of power. Bainimarama has certainly learnt from the past political mistakes of his military predecessors, Sitiveni Rabuka and Epeli Ganilau. Both former commanders made the miscalculation; it seems, of relinquishing their military command and basing their political ambitions on civilian political institutions. Rabuka used the Great Council of Chiefs to patronise his political party, the Soqosoqo ni Lewe ni Vanua iTaukei (SVT), and sanction his nationalist agenda. Insidious Taukei infighting involving its elite and fringe nationalist groups during Rabuka's prime ministership led to his downfall and the dismantling of the SVT. Ganilau, with the patronage of president and father-in-law Ratu Sir Kamisese Mara and Methodist reformists, formed the Veitokani Lewe ni Vanua Party (VLV) in 1999 and later in 2006, with business elites, cobbled together the moderate National Alliance Party. Both parties failed to draw mainstream Indo-Fijian or Taukei support. In Fiji's polarised ethnic politics Ganilau's elitist moderate alignment probably led to his demise and later falling out with Bainimarama. Ironically Ganilau, on venturing into politics, had chosen Bainimarama as his successor. Ever since, many senior officers have been purged or compelled to resign due to the personalised and political orientation of the commander.

\section{Military's ethnic paradox}

At the outset, the Achilles heel of Bainimarama and his officer elite's policy to reform Fiji's divisive communal society into an all-inclusive state based on civic nationalism lay in the exclusive ethnic makeup of

2 The 10 former military officers that make up the 33-member FijiFirst Party parliamentary members in government are V Bainimarama, T Natuva, J Konrote, P Tikoduadua, I Tuitubou, I Seruiratu, J Cawaki, N Rika, S Vunivalu and S Korolavesau. Incidentally, the opposition SOPDELPA Party has five former military officers in I Tikoca, V Tagivetaua, S Matanitobua, $\mathrm{K}$ Kiliraki and J Dulaki, accentuating the influence of the military in national politics as a whole. 
the military. After eight years of espousing the values of multiracialism over ethno-nationalism, the military remains overwhelmingly an indigenous Fijian institution, with all its Taukei shibboleths. The reason for this ethnic disparity perhaps is historical, but the fact that the military regime overlooks this national political paradox whilst simultaneously dismantling other Taukei institutions is an oddity. Given Fiji's vanua politics, it is arguable that Bainimarama has created a super fourth Taukei confederacy using the military, which sits above the three neo-traditional confederacies. Perhaps herein also lies the inherent institutional character flaw that apparently triggers the military to intervene in Fiji's ethnically based politics. I suggest that the ethnic homogeneity of the Fijian military, unlike the heterogeneous makeup of its Melanesian counterpart in Papua New Guinea, is decisive in fostering the coup phenomenon.

Bainimarama has openly engaged in national politics, using the advantages of his military position. He later rationalised his actions by claiming that 'only the military can bring about real political change'. This became a political mantra that appears to have gone down well among youthful voters who, in spite of numerous claims against the regime of human rights abuse, see in Bainimarama's strongman persona the necessary political catalyst for bringing about a multiracial Fiji. His muzzling of nationalist elements within the Methodist Church has also proved effective in dampening ethno-nationalist fervour and engendering a more universalist orientation in the Methodist hierarchy (Weir 2014).

By cleverly co-opting receptive serving military officers, Bainimarama enticed a clique of officers with accelerated promotion and handsome salary increases that have enabled him to build a strong political base while using the military as a nation-building institution. This developmental face of the military, spearheaded by the Engineer Rural Development Unit, Trade Training School and National School cadetship program, have been effectively propagandised by the Ministry of Information and its proxy media outlets such as the Fiji Sun newspaper and FBC TV to great effect. On the darker side, Bainimarama has used the institution as a coercive political tool to great effect and, with his protégé Brigadier Mosese Tikoitoga, continues to 
do so subtly. ${ }^{3}$ This patron-client relationship is the mainstay of the FF in spite of Tikoitoga's assurance that in future the military will be strictly 'politically neutral'. Hence the big question remains: will Fiji's third transition to democracy follow the Burmese model, where the military remains entrenched in the new democratic government, or evolve similarly to the Indonesian model where military influence is increasingly precluded in place of civilian democratic rule? I argue that the military's role as rationalised by the 2013 Constitution leaves the door ajar for further political intervention in the new democratic Fiji. This ambiguity in the military's constitutional role points ominously to a military that will remain a political force for at least the next decade.

\section{Open List Proportional Representation and the advantage of incumbency}

With an 84 per cent voter turnout on Election Day, the newly instituted open list proportional representative system, on the face of the polling results, favoured Bainimarama and his incumbent military regime's $\mathrm{FF}$, which won 59.2 per cent of the popular votes. In a post-election review, Fraenkel (2014) stated that some of the major characteristics of the new electoral system were:

a. the reduction of the voting age from 21 to 18 years, which accounted for some 28 per cent of registered voters;

b. the eligibility of dual nationality and overseas permanent residence registered voters, which accounted for 7,186 votes or 1.4 per cent of the total votes cast;

c. the 5 per cent threshold of votes to gain a parliamentary seat, thus handicapping smaller parties and independent candidates;

d. the abolishing of communal constituencies; and

e. a single national constituency.

3 Master Joseva Bilitaki's much publicised allegation of being assaulted by military intelligence officers after sending angry text messages to Bainimarama around election time was dropped by the Director of Public Prosecutions for lack of evidence. 
Invariably, the pre-election advantage of incumbency favoured Bainimarama's FF. The persecution of the opposition, especially former prime ministers Laisenia Qarase and Mahendra Chaudhry, the exorbitant civil servant pay rises and the vote-buying manifesto promises effectively foiled the opposition democratic front's late run in mustering voter support. Bainimarama's provoking rhetoric, bordering on political blackmail of 'you vote for me and there will be no coup', had its marked effect on voters. Furthermore, with half the population hovering on or beneath the poverty line, many voters were swayed by bread and butter issues as exemplified in the FF manifesto's promises of 'free water and milk'.

When all is said and done, the elections were the essential first step towards parliamentary democracy and the opening up of the political space that had been muted by draconian decrees in the previous eight years. Sceptics had serious doubts, given Bainimarama's track record, that the elections would eventuate. That it did take place on a relatively free and fair basis is a credit to the much maligned Fiji Elections Office and the Supervisor of Elections, although in the week before the elections Bainimarama's bombastic 'Suva will not burn again' statement, alluding to the 2000 Speight crisis, was political 'dog whistling' at best. In addition, the military's highly visible 'public exercises' in the week leading up to the elections almost certainly influenced undecided and impressionable youth voters as to who was the ultimate guarantor of public safety.

In military parlance, the Bainimarama regime had fought its opponents 'on ground of its own choosing'. The shaping of the 2014 elections 'battlefield' was cleverly executed, as in any well-constructed militarybased process. The opposition parties were 'fixed' and 'channelled' by the obstacles on the 'killing ground' well before the battle began. The high hurdles set by the election decree for political parties and candidates ensured an uneven playing field in the pre-election period. Scott MacWilliam, an election observer, had even suggested that a bigger victory margin would have been achieved by FijiFirst if a 48-hour election media blackout had not been decreed. This is because of the party's huge undeclared donor-funding from businesses, which could have been deployed to ramp up its propaganda until polling hour, especially as the regime was well in control of the media industry. 
Prior to the elections, Brigadier Tikoitoga's odd public comments further compounded the public's fears that the military would not remain neutral should Bainimarama lose the elections. The spectre of ethnonationalism was incessantly invoked by Bainimarama while Tikoitoga harked back to the 2000 coup, thus subtly reminding the public of Bainimarama's artfully airbrushed 'saviour' role. Interestingly, among coup-prone states, only Fiji's military have conducted coups to avert perceived ethnic conflict. In Fiji's case, the contentious anti-ethnonationalism rhetoric effectively justifies and may prolong the military's role in politics. With an ethno-nationalist Social Liberal Democratic Party as the principal opposition, Bainimarama can further strengthen the justification for the military's hardnosed approach via its proxyFijiFirst.

\section{The ethnic Gordian knot and the 'Glorious Revolution'?}

Has the past eight years of Bainimarama's military authoritarian rule, as symbolised by the abolition of communal constituencies, cut through the Gordian knot of 'old' ethnic politics and its multicomplex issues? Coup apologist Graham Davis (2014), like many of his ilk, was enthralled with the result and went so far as to proclaim Bainimarama's decisive election victory as a 'glorious revolution' in which 'he took a sledge hammer to the entire political edifice, smashed it to smithereens and then set about rebuilding Fiji into a modern nation-state that has been transformed almost at every level'.

In spite of Davis's enthusiastic endorsement, Bainimarama's legacy and performance as Prime Minister and Minister of Finance remains debatable. One serious concern has been highlighted by members of the UN Human Rights Council (UNHRC), meeting in October 2014, who found the 2013 Constitution seriously flawed and recommended a commission to undertake its comprehensive review. There were 137 other recommendations that were brought to the attention of Fiji's high-powered delegation of eight senior government members to Geneva, headed by Attorney General Aiyaz Sayed-Khaiyum. Robert Jackman, in comparing the performance of military regimes, had found that 'military governments have no unique effects on social change, regardless of level of economic development' (quoted in 
Perlmutter 1981, p. 118). The Auditor General's report from 2007-13 tabled in parliament stated that it has become abundantly clear there has been widespread abuse of public funds and blatant disregard of fundamental financial procedures'. Independent economist Professor Biman Prasad puts economic growth annually from 2006-13 on average at a paltry 0.1 per cent GDP. Furthermore, Janowitz states that in measuring overall economic development, the experience of military regimes is hardly impressive (Janowitz 1964, p. 79). The lack of public transparency and accountability in the last eight years due to authoritarian rule has indeed produced a society numbed by false 'feel good' propaganda churned out by a controlled and muted media industry.

Outspoken economist Professor Waden Narsey conservatively puts the total loss of potential GDP from 1987 to 2010 at close to FJD $\$ 10$ billion as a result of Fiji's coups. The revelation of the released Auditor General's report is damning on the regime, and indeed the military, under Bainimarama. During the 2006-07 budget period, an unauthorised FJD\$45.5 million was incurred by the military. What has played a major role in the survival of the Bainimarama regime has been the political support of superpower China. In the eight years of its authoritarian rule, in spite of the economic and political sanctions imposed by the West, the Bainimarama regime was able to resist the call for a prompt return to democracy because of Chinese economic aid and trade (Radio NZ 2014b). Indeed, much self-praise was generated by the Bainimarama regime due to its public infrastructure development record. Furthermore, Chinese President Xi Jinping's visit to Fiji after the elections, where he also met with leaders of Samoa, Vanuatu, Niue, Tonga, Federated States of Micronesia, Cook Islands and Papua New Guinea, underscores Beijing's backing of Fiji's new standing in the region.

Perlmutter, writing in the Cold War era prior to the rise of China, asserted that 'many observers may have been mistaken in attributing unique political skills to the military, whether directed toward progressive or conservative ends' (Perlmutter 1981, p. 117). Given that there are seven handpicked former senior military officers in Bainimarama's cabinet, it will be a challenge for them to display the independent and rigorous thinking vital to a transparent democratic 
society. ${ }^{4}$ The optimistic prognosis of a progressive military promoting social change does not stand up to empirical analysis either. In their examination of whether policies that favour the military reduce the risk of coups, Collier and Hoeffler 'have found if anything, their effect was perverse: high military spending may even increase the risk of coups' (Collier \& Hoeffler 2005, p. 2). The Fiji military's overspending record and expansion in non-core defence roles since the first coup in 1987, and after the coups of 2000 and 2006, verifies this assessment. By 2005, Bainimarama had developed a political agenda. This was clearly evident in Bainimarama's opposition to the Qarase government's National Security White Paper of that year. Obviously, the Qarase government saw the insolent military commander as a thorn in its side and was trying to get rid of him in early 2004 at the end of his contract. Bainimarama was adamant that any reform under the Qarase government would weaken the institution through a reduction in budget, retrenchment and more civilian control of the military. Under pressure from Bainimarama, the paper was shelved. The military's corporate power had won out.

A key question arising from this is how has this corporate identity developed over the years? Former vice president Ratu Joni Madraiwiwi, at a recent post-election symposium, warned that any dialogue with Bainimarama or the military as to its future role will have to be handled very carefully for obvious reasons (Radio NZ 2014a). As argued in a previous analysis (Baledrokadroka 2012a, p. 105), Fiji's participation in UN peacekeeping since 1978 has given the military an inflated corporate image that is now manifest in its perceived role of political conflict mediator.

\section{Fijian peacekeepers in the UNDOF Golan Heights hostage crisis}

In the lead-up to the elections, a number of Fijian soldiers serving with the UN Disengagement Observer Forces (UNDOF) were captured and held hostage by the jihadist al-Nusra group on the Golan Heights. This threatened to undermine Bainimarama's political campaign and split military solidarity. Questions were raised as to the wisdom of

4 The seven former RFMF officers included in the 20-member FF cabinet are V Bainimarama, T Natuva, J Konrote, P Tikoduadua, I Tuitubou, I Seruiratu and J Cawaki. 
deploying Fijian soldiers to the Golan when other nations such as Austria, Japan, Croatia and the Philippines were withdrawing their contingents due to the highly dangerous civil war in Syria that had spilled onto the Golan. As argued earlier (Baledrokadroka 2012b, p. 105), Fiji's international peacekeeping has become a determining factor, with unintended consequences for the internal stability of the nation. This role has justified an oversized military with a similarly disproportionate share of the national budget. Even though the soldiers were released unharmed on the eve of the elections through the diplomatic negotiations of Qatar, Fiji's proud international peacekeeping image was tarnished. Arguably, Fiji's policy of providing soldiers on demand for UN peacekeeping missions unwittingly provides the military with its expanded political role. At the time of writing, 1,100 or a third of the military's 3,300 regular forces soldiers are on active duty with international peacekeeping forces. ${ }^{5}$ An additional force of 5,000 active territorial and reservist soldiers, topped up by an annual recruitment of 300, provide peacekeeping replacements on six-monthly rotations. Hence, many youths see the military as a means of highly rewarding overseas employment. In spite of criticism during the Golan hostage crisis, Brigadier Tikoitoga revealed that Fiji was being invited by the UN Department for Peacekeeping Operations (UNDPKO) to provide more peacekeepers for UNDOF. After the Golan hostage crisis, the purchase of six $105 \mathrm{~mm}$ howitzers to upgrade obsolete artillery is also seen as a call by UNDPKO for Fiji to upscale its peacekeeping force protection armaments, given the high risk level in the volatile Southern Syrian border region with Israel. This FJD\$10.2 million acquisition was carried out on the unilateral authority of Bainimarama as Minister of Finance.

\section{Coup culture calculus}

The National Federation Party leader, Tupou Draunidalo, has asserted:

The coups in our country do not occur as an extension of widespread and sustained public disaffection. They occur after private and secretive consultations amongst private individuals, who then find the requisite personality in the military to carry out the coup. (Draunidalo 2014)

5 This consists of 339 all ranks with MFO Sinai, 270 all ranks with UNAMI Iraq and 500 all ranks with UNDOF Golan Heights. 
This resonates with Samuel Finer's disposition/opportunity calculus to explain military intervention in Fiji's politics (Finer 1962, p. 140). Finer identifies the disposition of the military elite, which is bound to its corporate and individual interests, as the push factor. The pull factor is the military's opportunity to intervene when a weakening of public support for government has occurred. In applying the calculus in the Fiji coups context, it can be seen that these push-pull factors of political forces were present. The coalescence of the political Taukei Movement with Rabuka prior to the 1987 coup, and with Speight and Taukei political elites prior to the 2000 overthrow of the coalition government led by the Fiji Labour Party's Mahendra Chaudhry, and Commodore Bainimarama's plotting with politicians, community leaders and legal experts prior to the 2006 coup, substantiates Finer's coup theory.

Unfortunately, the role of the military as set out in the 2013 Constitution does not promote a coup-free future, thus raising questions about the political intentions behind it. The document states that ' $[t]$ he role of the Republic of Fiji Military Forces is to ensure at all times the security, defence and well-being of Fiji and all its residents'. This clause can be used by the military to justify intervention in a political crisis. The appointment of the commander of the Republic of Fiji Military Forces by the Prime Minister, as prescribed in the Constitution, may encourage partiality in what should essentially be a politically neutral office.

\section{Conclusion}

According to renowned Chinese strategist Sun Tzu: 'He will win who, prepared, takes his opponents unprepared'. Bainimarama had boasted before the elections that his FijiFirst party would win 50 seats. While the military regime and its proxy political party enjoyed the advantages of incumbency, the opposition parties were hobbled by unrealistic deadlines and decrees. Other tactics deployed by Bainimarama included handouts and civil service pay increases on the one hand and threatening rhetoric on the other. These factors, combined with the new national single constituency system, clearly favoured FijiFirst. Fraenkel (2014) also contends that the new open list system handicapped opposition parties, as candidates were also 
competing against each other for votes to ensure a seat in parliament. He further suggests that the ethnic cleavage of the past was still a feature of the 2014 elections. Even though the new electoral system was designed to eradicate this colonial legacy, old habits of thought and political behaviour die hard and it will take at least another generation for ethnic politics to be expunged, if they ever are.

While some, such as Madraiwiwi, see the election outcome as a significant step to a coup-free future despite these problems (Radio NZ 2014a), others are convinced that the legitimation of Bainimarama's party through the polls means that the coup culture remains firmly embedded. Draunidalo (2014) rightly contends that it would now appear to military personnel back home that Fiji likes to endorse coup makers and/or their proxies at the polls. Crime and treason certainly pays'. In explaining how civilian support coalesces around coup makers in Fiji, Draunidalo is critical of coup apologists, especially legalists and academics. She echoes Finer's coup theory, in which opportunists unite with the military, as brashly stated by another 18th-century military commander: 'I begin by taking. I shall find scholars later to demonstrate my perfect right' (quoted in Draunidalo 2014).

In summary, this chapter has addressed, if not answered, two sets of key questions. First, has the election result under the new Constitution finally eradicated Fiji's coup culture, or does it provide encouragement for future extra-legal political putsches? Second, will the military in Fiji hold to its constitutionalised political role, or will it retreat from politics and adopt a neutral philosophy as promised by Brigadier Tikoitoga? Certainly, the ethos of an essentially apolitical role needs to be strongly inculcated into the military officer corps. The arrival after the elections of British Army officers to conduct training in military leadership and other subjects seems to auger well for a return by the RFMF to its core professional role. Furthermore, balancing the ethnic makeup of the military with Indo-Fijians will also send a signal that the FijiFirst government is genuine in creating an all-inclusive multiracial state. This is part of the equation for a stable democracy. The other part of the equation is to ensure that political elites do not coalesce with the military elite at critical junctures of political tension. Meanwhile, in the transition to democracy post elections, Professor Brij Lal's quip that the 'military will remain the unseen elephant in the room' 
is quite apt. The absurdity of the military as both agent and client of its patron, Bainimarama's FijiFirst government, whilst claiming to be the final guarantor of national security, remains a paradox.

\section{References}

Baledrokadroka, J 2012a, 'The unintended consequence of Fiji's international peacekeeping', Security Challenges, vol. 8, no. 4, Summer.

Baledrokadroka, J 2012b, 'Sacred king and warrior chief: The role of the military in Fiji politics', Unpublished PhD thesis, SSGM, The Australian National University, Canberra.

Collier, P and Hoeffler, A 2005, Coup traps; why does Africa have so many coup d'Etats? University of Oxford Press, Oxford.

Davis, G 2014, 'The New Democracy Begins', Grubsheet, 22 September. Viewed 19 November 2014 at www.grubsheet.com.au/the-newdemocracy-begins/.

Draunidalo T 2014, 'Fiji return to democracy: The 2014 elections and the coup culture', SSGM Workshop, 5 November 2014, The Australian National University, Canberra.

Finer, SE 1962, The man on horseback: The role of the military in politics, Pall Mall Press, London.

Fraenkel, J 2014, 'Fiji return to democracy: The impact of Fiji's switch to open list proportional representation, an analysis of the September 2014 elections', SSGM Workshop, 5 November 2014, The Australian National University, Canberra.

Goledzinowski, A 2014, 'Fiji Return to Democracy: Conduct of 2014 Fiji Elections', SSGM Workshop, 5 November 2014, The Australian National University, Canberra.

Janowitz, M 1964, The military in the political development of new nations, University of Chicago Press, Chicago.

Perlmutter, A 1981, Political roles and military rulers, Routledge, London. 
Radio NZ 2014a, 'Fiji elections 'significant step' to coup free future', 20 November. Available at www.radionz.co.nz/international/pacificnews/259832/fiji-elections-'significant-step'-to-coup-free-future.

Radio NZ 2014b, 'More Chinese Aid to Fiji 'people focused', 24 November. Available at www.radionz.co.nz/international/ pacific-news/260140/more-chinese-aid-to-fiji-'people-focused'.

Weir, C 2014, 'Fiji return to democracy: The election and the Methodist church', SSGM Workshop, The Australian National University, Canberra 
This text is taken from The People Have Spoken: The 2014 Elections in Fiji, edited by Steven Ratuva and Stephanie Lawson, published 2016 by ANU Press, The Australian National University, Canberra, Australia. 